\title{
Tutum Teorisi Açısından Ülke İmajı, Ürün İmajı ve Tüketici Satın Alma Niyeti
}

\author{
Tolga ŞENTÜRK ${ }^{*} \quad$ Burak KARTAL ${ }^{* *}$
}

\begin{abstract}
$\ddot{O} Z$
Ülke imajı marka imajında olduğu gibi ürünlerin dışsal özelliklerinden kabul edilmekte ve tüketici ürün değerlendirmeleri üzerine etkisi 1960 ’l y yllardan beri araştırllmaktadır. Ülke imajı üzerine yapılan çalışmalarda bugüne kadar pek çok etki modeli ve ölçeği kullanılmıştır. Fakat son dönemde ülke imajının tüketici ürün değerlendirmeleri üzerine yaptığı etkileri ortaya çıkarmak için en ideal model olarak tutum teorisi öne çıkarılmaktadır. Tutum teorisi, tüketicilerin bilișsel ve duygusal değerlendirmelerinin davranışlarına olan etkisini açılamada en etkili yöntem olarak görülmektedir. Araştırmamızda tutum teorisi çerçevesinde ülke imajının tüketici ürün değerlendirmelerine olan etkisi hem bilişsel hem de duygusal boyutta araştırılmıştır. Çalışmadan elde edilen bulgulara göre bir ülkeye ait ürün imajı ile söz konusu ürüne ilişkin satın alma niyeti tutumların bilişsel ve duygusal bileşeni tarafindan ayr ayrı etkilenmektedir. Bilişsel bileşen ve duygusal bileşen satın alma niyetini hem doğrudan hem de ürün imajı üzerinden dolaylı olarak etkilemektedir. Ancak duygusal imajın etkileri göreli olarak düşük kalmaktadır. Ortaya konan veriler ışığında Japonya'da üretilmiş ürünler için Türkiye'deki pazarlamacıların bilişsel ve duygusal ülke imajı ile ürün-ülke imajını pazarlama faaliyetlerinde kullanmalarının hedef kitle üzerinde önemli düzeyde etki ortaya çıkarabileceği görülmüş̧ür. Bununla birlikte ABD ve Fransa özelinde ise sadece ürün-ülke imajının (ilgili ülkeye ait genel ürün imajının) satın alma niyetine dikkate değer bir etki yaptığı tespit edilmiştir.

Anahtar kelimeler: Ülke imajı, ürün imajı, tutum teorisi, satın alma niyeti.

Jel Sintflandirmast: L15, M16, M31
\end{abstract}

\section{An Empirical Examination of the Relationships Among Country Image, Product Image and Customers' Purchase Intention from the Perspective of Attitude Theory}

\begin{abstract}
Country image is accepted as an extrinsic cue like brand image and its effect on consumers product evaluation has been studying since 1960s. Many effect models and scales has been used on country image researches so far. But recently, attitude theory is seen as the most proper model to find the effects of country image on consumer product evaluations. Attitude theory is pointed that it is the most effective method to explain the effects of cognitive and affective evaluations on the customer behaviors. Country image effects on the customer product evaluations studied both cognitive and affective level in our research. It is founded out in this research that product image of a given country and the buying intention for that product is effected both by cognitive and affective component of the attitudes. Cognitive and affective component effect buying intention both directly and indirectly through product image. But the effect of affective image on buying intention is relatively weak. In the light of datas, it was showed that using both cognitive and affective component of the country image and product-country image in marketing activities of Japanese products may occur considerable
\end{abstract}

\footnotetext{
* Dr. Öğr. Üyesi, İzmir Kâtip Çelebi Üniversitesi Sosyal ve Beşeri Bilimler Fakültesi, medya ve İletişim Bölümü, tolga.senturk@ikc.edu.tr

** Doç..Dr., Manisa Celal Bayar Üniversitesi İİBF Fakültesi, İşletme Bölümü, burakkartal@yahoo.com 
effect on target consumers. However, it was founded that only product-country image (general product image) of US and France did considerable effect on buying intention.

Keywords: Country image, product image, attitude theory, buying intention.

Jel Classification: L15, M16, M31

\section{GíRiş}

Teknolojik gelişimin hızlanması ile birlikte ürün özellikleri de birbirine çok yaklaşmıştır. Firmalar ürün konumlandırması yaparken en küçük farklılıkları bile göz önünde bulundurarak tüketicilerin zihninde farklı bir yer edinmek istemektedir. $\mathrm{Bu}$ amaç çerçevesinde kullanılabilecek pazarlama uygulamalarından biri de ürünün üretildiği ülke imajının ürünün imajına yansıtılmasıdır (Nebenzahl ve Jaffe, 1996). Zira ürünün üretildiği ülkenin imajı olumlu olduğunda, tüketiciler o ürünün imajını daha olumlu değerlendirmektedir (Roth ve Diamantopoulos, 2009).

Ülke imajı literatürü gelişmiş ülke ürünlerinin tüketiciler tarafından pozitif algılandığını öne süren sayısız araştırma içermektedir. Fakat tüm bu araştırmalar, örneğin Japon ürünlerinin Çinliler tarafından, Alman ürünlerinin İsrailliler tarafından, Fransız ürünlerinin Avustralyalılar tarafından olumsuz bir değerlendirmeye tabi tutulmasını açılayamamaktadır. Yine aynı araştırmalar ürünün menşeinin az gelişmiş belirli bir ülke olduğu halde tüketiciler tarafından olumlu algılanmasına da açıklık getirememektedir. Mevcut duruma bakıldığında kimi tüketiciler bazı gelişmiş ülke mallarına boykot uygularken, bazı tüketiciler de birtakım az gelişmiş ülke mallarına karşı olumlu bir tutum sergilemektedir; yani "buycott" uygulamaktadır (Kotler vd., 2000). Konuya bu açıdan bakıldığında ve ülke imaj1 literatürünün yaklaşık altmış yıllık bir geçmişi olduğu göz önüne alındığında, ülke imajının tüketiciler üzerinde ortaya çıardığı etkinin uzun yıllardır tam olarak izah edilemediği söylenebilir.

Çalışmamızda bu soruna çözüm üretmek adına, tutum teorisi temel alınarak, tüketicilerin genel ülke imajı ve belirli bir ülkede üretilen ürünler hakkındaki değerlendirmeleri açıklanmıştır. Araştırma çerçevesinde ABD, Japonya ve Fransa'nın genel imajları ile bu ülkelerde üretilen ürünler hakkındaki tüketici değerlendirmeleri ele alınmıştır. Ülke imajının bilişsel bileşeni ile duygusal bileşeninin tüketici ürün değerlendirmeleri ile satın alma niyetine ayrı ayrı ve beraberce yaptığg etkiler istatistiksel analiz yöntemleriyle açıklanmıştır.

\section{I.ÜLKE IMAJI ETKILERINI AÇIKLAMADA TUTUM TEORISİ}

Tutum teorisi bilişsel, duygusal ve davranışsal bileşenden oluşan yapısıyla, önceki etki modelleriyle kıyaslandığında, tüketici davranışlarını açıklamada daha fonksiyonel bir nitelik arz etmektedir (Laroche vd., 2005; Roth ve Diamantopoulos, 2009). Tüketici ürün değerlendirmelerinde tutumların bilişsel bileşenine odaklanan; yani ülke gelişmişlik düzeyi, zenginlik ve teknolojik seviye gibi unsurları kullanan çalışmalar, Çinlilerin Japon mallarına karşı olumsuz tutumlarını açıklayamazken, bilişsel bileşen dışında, tutumların duygusal bileşenini de ele alan çalışmalar; takdir etme, sempatiklik, barışseverlik, dostluk ve işbirliği gibi değişkenlerle söz konusu duruma açıklık getirebilmektedir (örn. Maher ve Carter, 2011; Wang vd., 2012). 
Önceki araştırmalarda yer alan etki modellerinin tamamı ülke imajı araştırmalarına getirilen eleştirilere açık bir yapı arz etmektedir. İlgili modeller ülke imajı konseptinin içyapısının açıklanması ihtiyacını karşılayamamaktadır (Brijs vd., 2011). Literatürde yer alan etki modellerinin tamamı tüketicilerin ürün değerlendirmedeki bilişsel süreçlerini ele alırken, duygusal süreçleri tamamen göz ardı etmiştir. Oysaki duygusal süreçlerin tüketicilerin karar alma davranışında bilişsel süreçlerden daha baskın olabildiğini bugüne kadar pek çok pazarlama araştırması ortaya koymuştur (Schoefer ve Diamantopulos, 2008). Araştırmacıların belirtilen bu eksikliklere karşı verdiği cevap "tutum teorisi" olmuştur. Bu teori yukarıda bahsedilen eksiklikleri gidermektedir. Ayrıca, ülke imajına yönelik güncel çalışmalarda temel etki modeli olarak kullanılma sıklığ 1 artmaktadır (örn., Alvarez ve Campo, 2014; Brijs vd., 2011, Laroche vd., 2005; Lee ve Ham, 2015; Li vd., 2014; Maher ve Carter, 2011; Roth ve Zabkar, 2011, 2015; Wang vd., 2012).

\section{II.ARAŞTIRMANIN MODELİ VE DEĞISSKENLERİ}

Araştırma modelinde (Şekil 1) tüketicilerin ürünün üretildiği genel ülke imajı algıları, ürün imajı algıları ve satın alma niyetleri bulunmaktadır. Çalışmada tüketicilerden genel ürün değerlendirmesi istenmiştir. Bu sebeple spesifik bir ürün ya da ürün grubu araştırmaya dâhil edilmemiştir. Yine genel ürün değerlendirmesi üzerine çalışılması dolayısıyla belirli bir ülkeye ait marka ya da markaların araştırmaya dâhil edilmesi uygun olamayacağından tüketicilerden marka konusunda da değerlendirme istenmemiştir. Bu sayede spesifik ürün ve markaların olası etkisi ortadan kaldırılmaya çalışılmıştır.

Çalışmada ülke imajı çerçevesinde araştırılacak ülkeler ABD, Fransa ve Japonya'dır. Bu ülkelerin seçiliş sebebi, hem genel bilgi çerçevesinde hem de ürün bilgisi çerçevesinde, tüketici aşinalığının var olduğu beklentisidir. Böylelikle ürün ve ülkelere ilişkin tüketici aşinalığının düşük olmasının ortaya çıkardığı değerlendirme problemlerinden kaçınılmaya çalışılmıştır. Araştırmada test değişkenleri olarak ülke imajının bilişsel ve duygusal bileşenleriyle, ürün imajı ve satın alma niyeti kullanılmıştır.

Şekil 1: Araştırma Modeli (Not: Kesik çizgi ürün imajı üzerinden dolaylı etkiyi ifade etmektedir)

oEnel OLKe imau

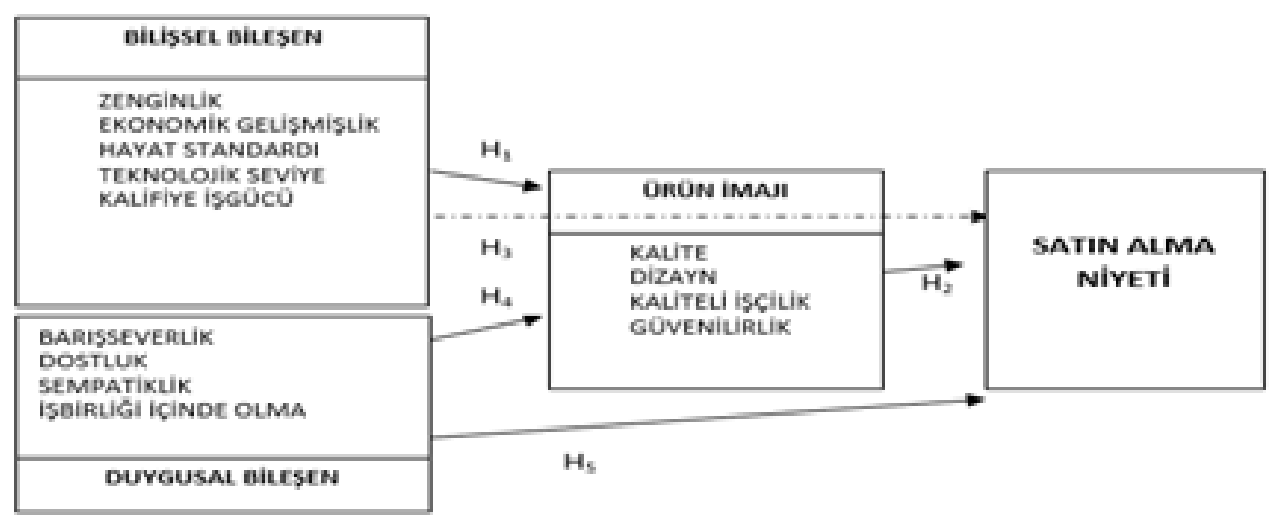




\section{A. Tüketicilerin Ülke İmajı Algıları ve Boyutları}

Araştırma modelinde görüleceği üzere ürünlerin üretildiği ülke imajının, söz konusu ülkenin ürün imajına ve tüketici satın alma niyetine etkisi olduğu düşünülmektedir. Ülke imajı algıları, bilişsel ülke imajı bileşeni ve duygusal ülke imajı bileșeni olmak üzere toplam iki boyutta; 9 değişken itibariyle ölçülmüștür.

- Ülke İmajının Bilişsel Bileşeni: Tüketicilerin genel ülke imajı algılarının bilişsel bileşeninin ölçümü için Parameswaran ve Pisharodi (1994), Laroche, Papadopoulos, Heslop ve Mourali (2005), Knight ve Calantone (2000) ve Wang ve arkadaşlarının (2012) çalışmalarından yararlanılmıştır. Tüketicilerin genel ülke imajı algılarının bilişsel bileşeni toplam beş değişken itibariyle ölçülmüştür: ülkenin zenginliği, ekonomik gelişmişliği, hayat standardının yüksekliği, teknolojik gelişmişlik seviyesi ve işgücünün kalifiye olması.

- Ülke İmajının Duygusal Bileşeni: Tüketicilerin genel ülke imajı algılarının duygusal bileşeninin ölçümünde Lala ve arkadaşları (2009) ile Wang ve arkadaşlarının çalışmasından (2012) yararlanılmıştır. Tüketicilerin genel ülke imajı algılarının duygusal bileşeni toplam dört değişken itibariyle ölçülmüştür: Ülkenin barışseverliği, dost bir ülke oluşu, işbirliği içinde olması ve sempatik bir ülke olmasi.

\section{B. Tüketicilerin Ürün İmajı Algıları}

Araştırma modelinde görüleceği üzere, ürün imajının, tüketicilerin satın alma niyetlerinde etkili olduğu düşünülmektedir. Ürün imajının ölçümü için Parameswaran ve Pisharodi (1994) ile Parameswaran ve Yaprak'ın (1987) ölçeklerinden yararlanılmıştır. Ürün imajı toplam dört değişken itibariyle ölçülmüştür: ilgili ülkenin ürünlerinin yüksek kaliteli oluşu, üstün dizayna sahip olması, kaliteli işçiliğe sahip olması ve güvenilir ürünler olması.

\section{Tüketicilerin Satın Alma Niyetleri}

Tüketicilerin satın alma niyetlerinin ülke imajı ve ürün imajından etkilendiği düşünülmektedir. Tüketicilerin satın alma niyetlerinin ölçümü için Laroche, Papadopoulos, Heslop ve Mourali (2005), Brijs ve arkadaşları (2011) ile Bozbay'ın (2007) çalışmalarından yararlanılmıştır. Tüketicilerinin satın alma niyetleri toplam üç değişken itibariyle ölçülmüştür: Ürünü satın almayı düşünmesi, ürünü satın alma olasılığının yüksek oluşu ve ürünü satın almayı istemesi.

Araştırma ölçeklerinin tamamı İngilizce bilgileri üst düzeyde üç farklı akademisyenin çapraz çevirilerine tabi tutulmuş ve anlam farklılığı oluşmasının önüne geçilmeye çalışılmıştır.

\section{Araştırmanın Hipotezleri}

Araştırmada ülke imajının ürün imajı ve satın alma niyeti üzerine etkileri tutum teorisi çerçevesinde açıklanmaya çalışılmaktadır.

-Ülke İmajının Bilişsel ve Duygusal Boyutları: Ülke imajının bilişsel boyutu, belirli bir ülkenin ekonomik gelişmişlik, hayat standartları, endüstrileşme, teknolojik gelişim, işgücünün eğitim seviyesi ve kabiliyetleri gibi özelliklerine dair tüketici inançları olarak kabul edilir. Ülke imajının duygusal boyutu ise belirli bir ülke hakkında tüketicilerin sevme-sevmeme, pozitif-negatif olma gibi duygusal değerlendirmeleri olarak kabul edilir. Bilişsel ve duygusal imajı birbirinden 
ayırmanın önemi ise bu iki boyutun tüketiciler tarafından değerlendirilmesinin birbiriyle tutarsız olabilmesinden kaynaklanmaktadır. Örneğin ABD'de yaşayan Arap asıllılar İsrail'e karşı negatif eğilimlidirler, fakat İsrail'de üretilen optik ürünlerin kalitesini takdir etmektedirler (Obermiller ve Spanberg, 1998). Çinliler de Japonya'nın ekonomik gelişmişliğini ve teknolojik üstünlüğünü bilseler de, tarihte yaşadıkları Japon işgali nedeniyle Japon mallarını olumsuz değerlendirmektedirler (Pewglobal, 2006).

•Bilişsel Ülke İmajı, Ürün İmajı ve Satın Ama Niyeti: Ülke orijini üzerine yapılan araştırmalar genel olarak ürün imajının (örn. İşçilik, inovasyon, teknolojik gelişmişlik gibi) ürün kalitesini nasıl etkilediğini ölçmüş ve incelemiştir (Roth ve Diamantopouolos, 2009; Papadopuolos ve Heslop, 1993). Ayrica söz konusu literatürde, bir ülkenin ürün imajının ürünün kalite algısını doğrudan etkilediği ayrıntılı bir şekilde açıklanmıştır.

Ülke imajının satın alma niyetine etkisi, öncelikli olarak, belirli bir ülke ürününün özellikleri hakkında oluşan tüketici algısıyla ortaya çıkmaktadır. Yani tüketicinin zihninde örneğin Alman otomobillerinin kalitesine ilişkin bir imaj oluşmakta, daha sonra da bir Alman otomobiline yönelen satın alma niyetinde bu imajın etkisi görülmektedir. Böylece bilişsel ülke imajı, ürün imajı ve satın alma niyeti arasında bir ilişki olduğu ortaya çıkmaktadır. Buradan özellikle bilişsel ülke imajının (yani ülkenin ekonomik ve teknolojik seviyesinin), ilgili ülkenin ürün imajını (örn. uzun ömürlü, iyi tasarlanmış, kaliteli işçilik vs.) etkilediği anlaşılır. $\mathrm{Bu}$ da sırasıyla ürünün algılanan kalitesine, sonra da satın alma niyetine etki eder. Diğer bir deyişle bilişsel ülke imajı ürün imajına şekil verse de, satın alma niyetini doğrudan etkilemez. Bunun yerine bilişsel ülke imajı ürün imajı üzerinden satın alma niyetini etkileyen dolaylı bir kanal olarak işlev görür (Wang vd., 2012:3). Laroche ve arkadaşlarının (2005) tespiti de buna paraleldir. Söz konusu araştırmacıların tespitine göre, ülke imajının bilişsel bileşeninin etkisi esasen ürün imajında ortaya çıkmaktadır. Dolayısıyla bilişsel bileşenin bir etki hiyerarşisinden bahsetmek mümkündür. Bu hiyerarşiye göre bilişsel bileşen ürün imajı üzerinde, satın alma niyetine göre daha büyük bir etki ortaya çıkaracaktır.

$\mathrm{Bu}$ tip bir düşüncenin Han'ın (1989) genelleştirme (halo) etkisi ile çıkarsama (summary construct) etkisi etrafında süren tartışmaları bağdaştırması mümkündür. Halo (genelleştirme) argümanı, eğer tüketiciler ürünlere aşina ise ülke orijini gibi satın alma niyetine dolaylı etki yapabilecek faktörlerden etkilenmelerinin düşük olasılık olduğunu söyler. Fakat buna rağmen bir ürüne aşinalık arttıkça, tüketicilerin içlerini rahatlatmak adına, ülke orijini bilgisine daha çok dikkat ettiklerini belirten araştırmalar da mevcuttur (örn. Johansson, 1989; Johansson ve Nebenzahl, 1986).

$\mathrm{Bu}$ tarz bulguların daha iyi anlaşılabilmesi ürün imajı ile ülke imaj1 etkilerinin birbirinden ayrıştırılmasıyla mümkün olabilir. Tüketiciler belirli bir ülkenin ürünü hakkında az bir bilgiye sahip olduklarında, ürünün kalitesini değerlendirebilmek adına o ülke için sahip oldukları basmakalıp düşüncelere ya da bilişsel ülke imajına atıf yapacaklardır. Bu tip durumlarda bu tarz inançlar, kalite değerlendirmeleri yoluyla satın alma niyetini etkileyen ürün imajı şeklinde 
karşımıza çıkar. Örneğin, Almanya'nın gelişmiş bir ülke olduğuna inan bir tüketici, hemen hiçbir bilgi sahibi olmadığı Alman malı bir şarjlı süpürgeyi değerlendirdiğinde Almanya hakkındaki bilişsel ülke imajını kullanarak zihninde bir ürün imajı oluşturur. Bu tüketici söz konusu şarjlı süpürgeyi kuvvetle muhtemel kaliteli olarak algılayacaktır ki, bugüne kadar yapılan pek çok araştırma bunu göstermiş̧ir (örn. Apil ve Kaynak, 2010; Cengiz ve Kırkbir, 2007). Bununla beraber tüketiciler belirli bir ülkeye ait ürünler hakkında bilgi sahibi ise, kalite değerlendirmeleri için ülke imajından ziyade dayanıklılık, dizayn üstünlüğüu, ekonomik kullanım gibi unsurları barındıran ürün imajını kullanırlar. Yani Mercedes otomobil hakkında yeterli bilgiye sahip olan bir tüketici Almanya hakkında sahip olduğu bilişsel ülke imajını kullanmaz. Mercedes otomobilin ürün imajı kalite değerlendirmesi için tüketiciye yeterli gelecektir. Bu sebeplerden ülke imajı satın alma davranışını ürün imajı yoluyla dolaylı olarak etkileyebilmektedir. Diğer bir deyişle ülke imajının bilişsel yönü (ülkenin ekonomik ve teknolojik seviyesi), ülkenin ürün imajını (dayanıklılık, işçilik vs.) etkileyecek, bu da sırasıyla seçim kararlarını ve satın alma niyetini etkileyecektir. Söz konusu durumda da bilişsel ülke imajının ürün imajına etkisi, satın alma niyetine olan etkisinden daha büyük olacaktır. Bilişsel imajın satın alma niyetine etkisi aynı zamanda dolaylı olacaktır. Bu sebeple şu şekilde üç hipotez kurulabilir:

H1: Bilişsel ülke imajı ilgili ülkenin ürün imajını etkiler.

H2: Bir ülkenin ürün imaj1 ilgili ülkenin ürünlerine ilişkin satın alma niyetini doğrudan etkiler.

H3: Bilişsel ülke imajı ilgili ülkede üretilmiş ürünlere ilişkin satın alma niyetini dolaylı olarak etkiler.

•Duygusal Ülke İmaj1, Ürün İmaj1 ve Satın Alma Niyeti: 1960'lı yıllardan 2000'lere kadar pek çok araştırmacı (örn. Jones ve Ashmore, 1973; Knight ve Calantone, 2000; Papadopoulos ve Heslop, 1993) ülke imajı boyutları içerisinde duygusal boyutun varlığını kabul etse de, bu boyutu araştırmalarına yansıtanların sayısı çok sınırlı kalmıştır. Ülke imajı sadece tüketicilerin zihnindeki bilişsel basmakalıp düşünceleri harekete geçiren bir olgu değildir. $\mathrm{O}$ aynı zamanda kalite değerlendirmeleri yoluyla satın alma niyetini etkilemekten başka, ülke hakkındaki duygusal değerlendirmelerle satın alma niyetine etki edebilir.

Çeşitli çalışmalar ülke orijinin tüketiciyi bilişsel olarak harekete geçiren ürün işaretlerinden sadece biri olmadığını göstermiştir. Wyer ve arkadaşları (Hong ve Wyer,1989,1990a; Li ve Wyer, 1994) ülke orijinin tek özelliğinin ürün kalitesi konusunda fikir veren bir sembol olmak şeklinde anlaşılmaması gerektiğini ortaya koymuşlardır. Ülke orijini tüketiciler için bir kalite göstergesi olmaktan başka, sembolik ve duygusal anlamlar da taşımaktadır. Ülke orijini bir ürüne statü, otantizm ve egzotiklik kazandırabilir (Li ve Monroe, 1992). Dahası ülke orijini bir ürünü duygular, duyular ve ritüellerle bağlantılı olarak zengin bir ürün-ülke imaj dünyasına bağlayabilir (Askegaard ve Ger, 1998). Fournier (1998) ülke orijinin ürünleri, belirli ürün ve markalara karşı güçlü bir duygusal bağ oluşturan ulusal kimlikle ilişkilendirdiğini bulmuştur. Araştırmacı ikinci jenerasyon Amerikalı İtalyan bayanları üzerine bir inceleme yapmış ve söz konusu bayanların özellikle 
gıda ürünleri çerçevesinde İtalyan ürünlerine karşı yüksek bir ilgilenimi olduğunu görmüştür. Bu tip bir birey için İtalyan ürünlerinin çok büyük bir duygusal ve sembolik çağrışımı olduğu tespit edilmiştir. Botschen ve Hemettsberger (1998) de tüketicilerin ülke orijinini sadece kalite ile değil, duygular, ulusal iftiharlar ve geçmişteki gezilere dair hatıralarla ilişkilendirdiğini bulmuştur. Bu sembolik ve duygusal çağrışımlar ülke orijinini “ifade edici” ya da "imaj” özelliğine dönüştürür. Bu özellikler de, ülke imajı konsepti çerçevesinde, tüketici tercihlerinin önemli bir belirleyicisi ve marka değerinin önemli bir kaynağı olur (Lefkoff-Hagius ve Mason, 1993).

Tüketiciler hemen her konuda duyguları aracılığıyla değerlendirmede bulunup tutumlarını şekillendirebilirler. Duygular bu nedenle hangi inançların şekilleneceği, bunların nasıl değerlendirileceği ve tercihlerde inançların ne kadar ağırlığının olacağının belirlenmesinde hayati bir rol oynar (Wang vd., 2012). Bilişsel ve duygusal ülke imajı boyutları tutarlı olduklarında, yani bir ülke için ikisi de olumlu ya da ikisi de olumsuz olduğunda, duygular tüketicilerin bilgi işlemesine katkıda bulunur. Bilişsel ve duygusal ülke imajı tutarsız olduğunda ise, duygusal boyut bilgi işleme sürecini engelleyebilir. Örneğin, Çinlilerin Japon mallarına karşı gösterdiği duygusal tepki gibi. Bu nedenle duygusal ülke imajının satın alma niyetini doğrudan etkilediği söylenebilir. Ayrıca bu etkilerin ürün imajından ve ürün kalite değerlendirmelerinden de bağımsız olduğundan bahsedilebilir. Söz konusu bilgiler 1şında şu şekilde iki hipotez kurulabilir:

H4: Duygusal ülke imajı ilgili ülkenin ürün imajını etkiler.

H5: Duygusal ülke imajı ilgili ülkenin ürünlerine ilişkin satın alma niyetini doğrudan etkiler.

\section{III.VERİ VE BILLGILERİN ANALİi̇}

Manisa Celal Bayar Üniversitesi Eğitim Fakültesi ve Demirci Meslek Yüksekokulu öğrencileri araştırmanın örneklem kitlesini oluşturmaktadır. Araştırma ölçeklerini içeren anket formu aracıllı̆ıyla 425 denekten veri toplanmıştır. Birçok ülke imajı çalışması araştırma evreni olarak öğrenci kullanımına gitmiştir (örn. Tse ve Gorn, 1992; Ulgado ve Lee, 1993; Chinen vd., 2000). Liefeld (1993), araştırma evrenini öğrencilerin oluşturduğu çalışmalar ile hane halkına uygulanan araştırmalar arasında sonuçları açısından anlamlı bir farklılık olmadığını tespit etmiştir.

Kolayda örnekleme yöntemi çalışmanın örnekleme metodu olarak belirlenmiştir. Uygulama öncesinde deneklere ihtiyaç duyacakları bilgiler verilmiş ve anket soruları cevaplanırken deneklerin birbirlerinden etkilenmemeleri sağlanmıştır. Anket sorularında genellikle ölçek olarak 5'li likert ölçeği kullanılmıştır. Çalışmada değişkenler arasındaki nedensellik bağının yorumlanabilmesi amacıyla Regresyon Analizi uygulamıştır. Veri analizlerine geçilmeden önce araştırmada kullanılan ölçeklerin geçerlilik ve güvenilirlik analizleri yapılmıştır. Analizlerde SPSS 20 (Statistical Package for Social Sciences) paket programı kullanılmıştır. 


\section{A.Ölçeklerin Geçerliliği Ve Güvenilirliği}

Çalışmamızda, ölçeklerin geçerliliğini tespit etmek amacıyla keşfedici faktör analizi kullanılmış ve ilgili analizin uygunluğunu test etmek için de KMO Örnekleme Uygunluğu Ölçümü (Kaiser-Meyer-Olkin Measure of Sampling Adequacy) ile Bartlett's Testi (Bartlett's Test of Sphericity) uygulanmıştır. Faktör yükleri, korelasyon matrisinin oluşturulması ve bu matrise varimax rotasyonunun uygulanmasıyla belirlenmiştir.

Çalışmamızda ölçeklerin güvenilirliklerini test etmek amacıyla Cronbach's alfa katsayısı yöntemi kullanılmıştır. Her bir ölçeğe Cronbach's alfa katsayısı yöntemi uygulanmış, sonuçlar geçerlilik analizi tablolarıyla birlikte sunulmuştur.

Tablo 1: Faktör Analizine Uygunluk

\begin{tabular}{|cccccc} 
& KMO & Bartlett's & & KMO & Bartlett's \\
\hline $\begin{array}{c}\text { Bilisssel } \\
\text { Ullke İmaj1 }\end{array}$ &, 750 &, 001 & $\begin{array}{c}\text { Ürün-Ülke } \\
\text { İmaji }\end{array}$ &, 804 &, 001 \\
$\begin{array}{c}\text { Duygusal } \\
\text { Ü. İmaj1 }\end{array}$ &, 644 &, 001 & $\begin{array}{c}\text { S. Alma } \\
\text { Niyeti }\end{array}$ &, 748 &, 001 \\
\hline
\end{tabular}

Tablo 1'de görüldügüü üzere faktör analizi için gerekli KMO ve Bartlett's Testi katsayıları anlamlıdır. Çünkü matristeki korelasyonlar anlamlıdır.

Tablo 2: Faktör Analizi Sonuçları

\begin{tabular}{|c|c|c|c|}
\hline & $\begin{array}{l}\text { Faktör } \\
\text { Yüküu }\end{array}$ & $\begin{array}{c}\text { Alfa } \\
\text { Değeri }\end{array}$ & $\begin{array}{l}\text { Açıkladığı } \\
\text { Varyans }\end{array}$ \\
\hline Bilişsel Ülke İmaj1 & & ,777 & $\% 54,8$ \\
\hline Gelişmiş Ekonomi & ,847 & & \\
\hline Yüksek Hayat Standard1 & ,805 & & \\
\hline Gelişmiş Teknoloji & ,734 & & \\
\hline Zenginlik & ,720 & & \\
\hline Kalifiye İşgücü &, 563 & & \\
\hline Duygusal Ülke İmajı & & ,680 & $\% 56,7$ \\
\hline Dost & 902 & & \\
\hline Barışsever & ,881 & & \\
\hline İşbirliğinde & ,642 & & \\
\hline Sempatik &, 514 & & \\
\hline Ürün-Ülke İmajı & &, 851 & $\% 69,2$ \\
\hline Üstün Dizayn & 853 & & \\
\hline Güvenilir Ürünler & ,831 & & \\
\hline Kaliteli İșçilik & ,826 & & \\
\hline Yüksek Kaliteli Ürünler & 817 & & \\
\hline Satın Alma Niyeti & & ,914 & $\% 85,5$ \\
\hline Satın almayı düşünürüm & ,937 & & \\
\hline Satın almak isterim & 934 & & \\
\hline $\begin{array}{l}\text { Satın alma olasılığım } \\
\text { yüksektir }\end{array}$ & ,903 & & \\
\hline
\end{tabular}

Tablo 2'de faktör yük değerleri anket formundan çıkarılması gereken herhangi bir değişken olmadığını göstermektedir. 


\section{B.Araştırma Verilerinin Analizi}

Çalışmamızda güvenirlilik ve geçerlilik testleri yapıldıktan sonra, araştırmaya dâhil edilen ülkelerin tüketicilerden aldığı değerlerin aritmetik ortalamaları saptanmıştır. Bunun ardından çoklu regresyon analizlerine geçilerek bu başlık tamamlanmıștır.

\section{Araştırmaya Dâhil Edilen Ülkelerin Tüketicilerden Aldığı Değerlerin Aritmetik Ortalamaları}

Araştırmaya katılan tüketiciler ABD, Fransa ve Japonya'yı bilişsel ve duygusal ülke imajı ile ürün imajı ve satın alma niyeti açısından değerlendirmiştir. Aşağıda yer verilen tabloda (Tablo 3) görüleceği üzere, araştırmaya dâhil edilen dört değişkenin tamamında Japonya en yüksek değerlendirmeye sahip olmuştur. ABD duygusal ülke imajı hariç tüm değişkenlerde ikinci sıradadır. Fransa ise duygusal ülke imaj1 değerlendirmelerinde ikinci, diğer tüm değişkenlerde ise üçüncü olmuştur.

\begin{tabular}{|c|c|c|c|c|}
\hline & ABD & FRANSA & JAPONYA & SIRALAMA \\
\hline Bilişsel İmaj & 4,15 & 3,72 & 4,24 & Japonya $>$ ABD $>$ Fransa \\
\hline $\begin{array}{l}\text { Duygusal } \\
\text { İmaj }\end{array}$ & 2,14 & 2,38 & 3,56 & Japonya $>$ Fransa $>$ ABD \\
\hline Ürün İmajı & 3,56 & 3,25 & 3,85 & Japonya $>$ ABD $>$ Fransa \\
\hline $\begin{array}{l}\text { Satın alma } \\
\text { Niyeti }\end{array}$ & 3,20 & 3,04 & 3,80 & Japonya $>$ ABD $>$ Fransa \\
\hline
\end{tabular}

\section{Regresyon Analizleri}

Tablo 4: Araştırmaya Dâhil Edilen Ülkelerin Bilişsel Ülke İmajının Ürün İmajı Üzerindeki Etkisini Ölçmek İçin Uygulanan Regresyon Analizinin Özet Tablosu

ÜLKE

\begin{tabular}{cccc} 
& $R$ & $R^{2}$ & ETKİ EDEN DEĞIŞKENLER \\
\hline Japonya &, 607 &, 368 & - Yüksek hayat standardi $(, 319)$ \\
& & & -Kalifiye işgücü $(, 282)$ \\
ABD &, 402 &, 161 & - Gelişmiş Ekonomi $(, 194)$ \\
& & & -Kalifiye işgücü $(, 149)$ \\
Fransa &, 444 &, 197 & -Zenginlik $(, 097)$ \\
& & & -Gelişmiş ekonomi $(, 214)$ \\
& & & -Kalifiye işgücü $(, 144)$
\end{tabular}

Yukarıdaki tabloya (Tablo 4) bakıldığında bilişsel ülke imajının ürün imajına etki yaptığı hipotezinin doğrulandığı görülmektedir. Ancak söz konusu etki ülkeden ülkeye değişebilmektedir. Bilişsel ülke imajının ürün imajına etkisi hem değişkenler hem de katsayılar boyutuyla ülkeden ülkeye farklılık göstermektedir. $A B D$ ve Fransa için bilişsel ülke imajının ürün imajına etkisi olduğu söylenebilse de, bu etkinin düşük seviyede gerçekleştiği görülmektedir. Fakat yine de pazarlamacılar için göz ardı edilebilecek bir düzey olduğu söylenemez.

Japonya örneğine bakıldığında ise R2 değerinin \%37'lik bir oranla yüksek seviyede gerçekleştiği görülmektedir. Günümüzün yoğun rekabet ortamında ürün 
imajına \%37 oranında etki yapacak bir faktör pazarlamacılar tarafından dikkat edilmesi gereken bir olgudur. Bu sebeple bilişsel ülke imajının, ülkeden ülkeye değişmekle birlikte, ürün imajı üzerinde etkili olduğu söylenebilir. Bu nedenle hipotez $\mathrm{H} 1$ kabul edilmiştir.

Tablo 5: Araştırmaya Dâhil Edilen Ülkelerin Ürün İmajının Satın Alma Niyeti Üzerindeki Etkisini Ölçmek İçin Uygulanan Regresyon Analizinin Özet Tablosu

\section{ÜLKELER}

\begin{tabular}{|c|c|c|c|}
\hline & $R$ & $R^{2}$ & ETKİ EDEN DEĞİSSKENLER \\
\hline Japonya & ,761 & ,568 & $\begin{array}{c}\text {-Kaliteli işçilik }(, 338) \\
\text {-Üstün dizayn }(, 278) \\
\text {-Yüksek kaliteli ürün }(, 108)\end{array}$ \\
\hline ABD & 491 & ,241 & $\begin{array}{l}\text {-Güvenilir ürünler }(, 258) \\
\text {-Üstün dizayn }(, 258) \\
\text {-Kaliteli işçilik }(, 128)\end{array}$ \\
\hline Fransa & 493 & ,243 & $\begin{array}{l}\text {-Kaliteli iş̧ilik }(, 283) \\
\text {-Güvenilir ürünler }(, 244) \\
\text {-Üstün dizayn }(, 175)\end{array}$ \\
\hline
\end{tabular}

Yukarıdaki tabloya (Tablo 5) bakıldığında ülkelere ilişkin ürün imajının (ürün-ülke imajının) satın alma niyetine etki yaptığı hipotezinin (H2) doğrulandığ1 görülmektedir. Ancak söz konusu etki ülkeden ülkeye değişebilmektedir. ABD ve Fransa örneğinde görüldüğü gibi, ürün imajının satın alma niyetine olan etkisi ülke bazında düşük seviyede gerçekleşebilmektedir. Bunun dışında Japonya örneğinde görüldügüü üzere etki önemli seviyelerde gerçekleşebilmektedir. Satın alma niyetine etki eden değişkenlerin ve bunların katsayılarının da ülkeden ülkeye değiştiği görülmektedir.

Japonya örneğine bakıldığında R2 değerinin \%57'lik bir oranla yüksek seviyede gerçekleştiği görülmektedir. Günümüzün yoğun rekabet ortamında ürünülke imajı gibi satın alma niyetine $\% 57$ oranında etki yapabilecek bir faktör pazarlamacılar tarafından göz ardı edilemez. Bu sebeple ürün-ülke imajının, derecesi ülkeden ülkeye değişmekle birlikte, satın alma niyeti üzerinde etkili olduğu söylenebilir. Bu nedenle hipotez $\mathrm{H} 2$ kabul edilmiştir.

Araştırmada ele alınan hipotez H3'ün analiz edilmesi için aracı değişken olan ürün-ülke imajının regresyon analizine tabi tutulması gerekmektedir. Arac1 değişken analizi için İslamoğlu ve Alnıaçık (2016:408)'da önerilen süreç ve SPSS programı Process 3.2 makrosu kullanılmıştır. Bu analizde her ülke için Satın alma niyeti - PB (Y - bağımlı değişken), Bilişsel ülke imajı - BUI (X - bağımsız değişken) ve Ürün imaj1 - PI (M - aracı değişken) olarak belirlenmiştir. Bulgular Şekil 2'de katsayı ve anlamlılık değerleri ile ülkeler bazında verilmiştir. Buna göre, $A B D$ ve Fransa için ürün imajı, bilişsel ülke imajı ve satın alma niyeti arasındaki ilişkide tam aracı rolüne sahiptir. Ancak Japon ürünleri için durum farklılık göstermektedir. $\mathrm{Bu}$ ürünlerde ürün imajının güçlü biçimde aracılık etmesine ek olarak bilişsel ülke imajı da diğer iki ülkede gözlenen toplam etkiyi sadece direkt olarak gerçekleştirmektedir. Bir başka deyişle Japonya için ürün imajı söz konusu ilişkide sadece kısmi aracı rolüne sahiptir. Bununla beraber bilişsel ülke imajının 
satın alma niyeti üzerindeki toplam etkisinin yaklaşık olarak üçte ikisi ürün imajı aracılığıyla gerçekleşmektedir.

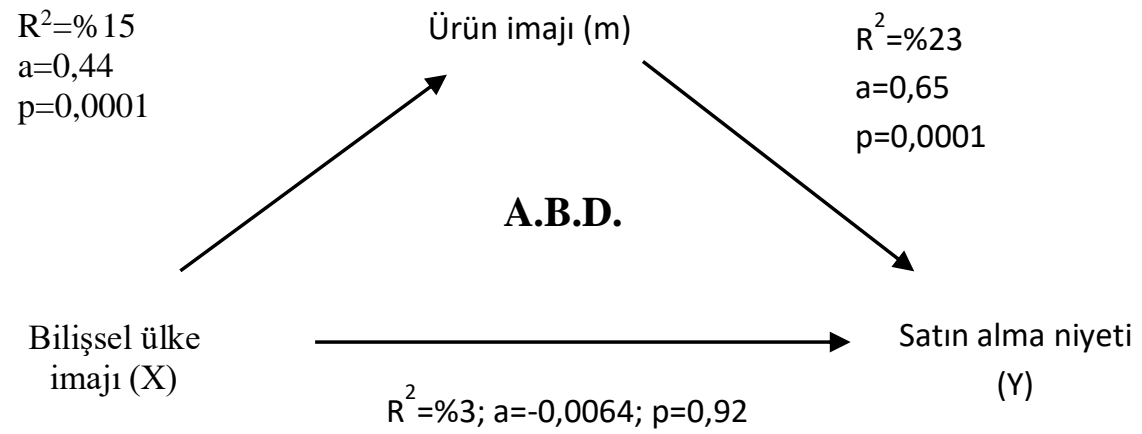

X'in Y üzerindeki dolaylı etkisi: $a=0,28 ; p=0,0002$

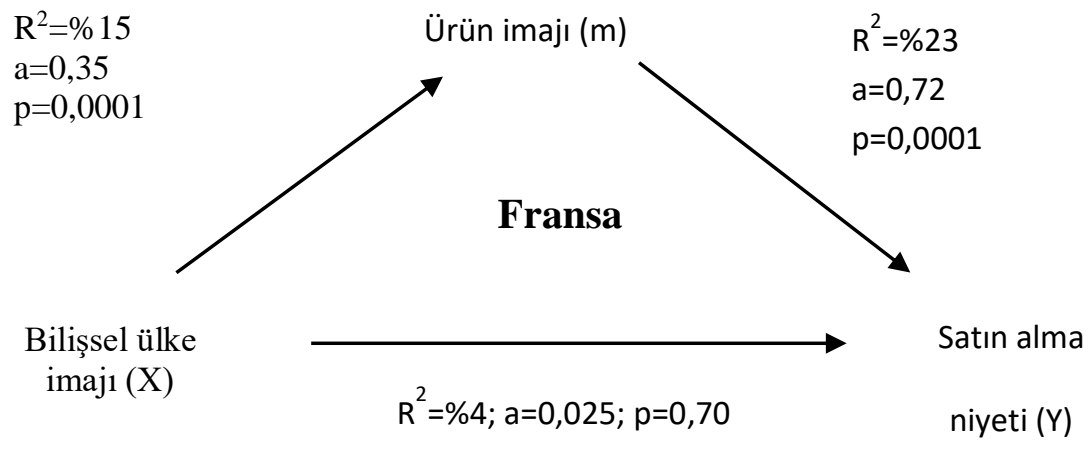

$\mathrm{X}^{\prime}$ 'in Y üzerindeki dolaylı etkisi: $\mathrm{a}=0,25 ; \mathrm{p}=0,0001$

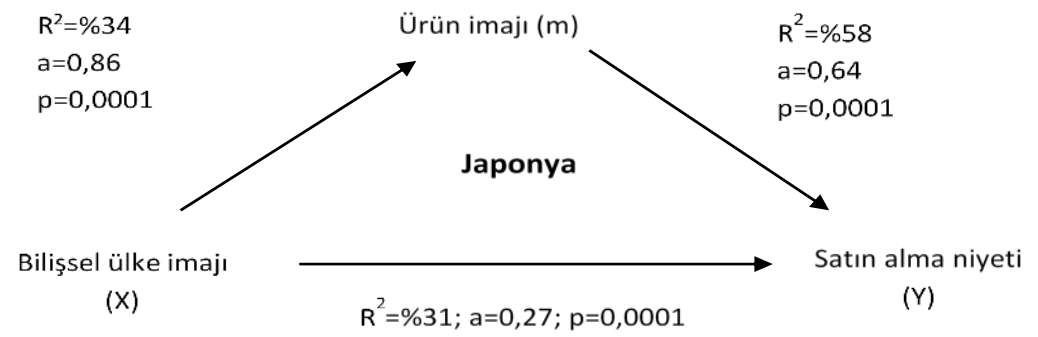

$X^{\prime}$ in Y üzerindeki dolaylı etkisi: $a=0,55 ; p=0,0001$; toplam etkisi $a=0,82 ; p=0,0001$

Japonya örneğine bakıldığında bilişsel ülke imajındaki bir birimlik değişme satın alma niyetinde toplamda 0.82 birimlik artışa yol açmaktadır. Aracı değişkenle birlikte bilişsel ülke imajı satın alma niyetine anlamlı ve yüksek bir etki yapmaktadır. Günümüzün yoğun rekabet ortamında böylesi bir etkinin ihmal edilmemesi gerekir. Yukarıda özetlenen sonuçlara bakılarak ABD ve Fransa'da 
bilişsel ülke imajının satın alma niyetine ürün-ülke imajının tam aracıllı̆ı ile, Japonya da ise kısmi aracılığı ile etki yaptığı görülmektedir. Bu bulgular hipotez H3'ü desteklemektedir.

Tablo 6: Araştırmaya Dâhil Edilen Ülkelerin Duygusal Ülke İmajının Ürün İmajı Üzerindeki Etkisini Ölçmek İçin Uygulanan Regresyon Analizinin Özet Tablosu

\begin{tabular}{|c|c|c|c|c|}
\hline Ülkeler & $\begin{array}{c}\text { Regresyon Analizi } \\
R \text { Değeri }\end{array}$ & $\begin{array}{l}\text { Regresyon } \\
\text { Değeri }\end{array}$ & $\begin{array}{ll}R^{2} & \text { EtkiEden } \\
& \text { Katsayıları }\end{array}$ & Değişkenler \\
\hline ABD & ,243 (\%24) &, $059(\% 6)$ & & $\begin{array}{l}\text {-İşbirliğinde }(, 127) \\
\text {-Sempatik }(, 067)\end{array}$ \\
\hline Fransa & ,240 (\%24) &, $055(\% 6)$ & & $\begin{array}{l}\text {-Barışsever }(, 105) \\
\text {-Sempatik }(, 089)\end{array}$ \\
\hline Japonya & ,500 (\%50) &, $250(\% 25)$ & & $\begin{array}{l}\text {-Barışsever }(, 222) \\
\text {-Sempatik }(, 390)\end{array}$ \\
\hline
\end{tabular}

Araştırma çerçevesinde değerlendirilen duygusal ülke imajı ile ürün-ülke imajı arasındaki ilişki (Tablo 6) bize önemli bilgiler sunmaktadır. Öncelikle duygusal ülke imajı ile ürün-ülke imajı arasındaki ilişkinin varlığının ve şiddetinin ülkeden ülkeye değiştiği söylenmelidir. Bundan başka duygusal ülke imajını oluşturan değişkenlerin her biri ürün imajı üzerinde etkili olmamaktadır. Örneğin "dostluk" duygusunu ölçen değişken hiçbir ülkede geçerli çıkmamıştır. Yine "barışsever", "işbirliğinde" ve "sempatik" değişkenlerinin bir kısmı belirli bir ülke için geçerli değişkenler olurken, diğer bir kısmı da bir başka ülke için geçerli olabilmektedir. Yani duygusal ülke imajı ile ürün-ülke imajı arasındaki ilişkinin bu boyutu da ülkeden ülkeye değişmektedir. Söz konusu bulgular bilişsel ülke imajının ürün imajına yaptığg etki ile karşılaştırıldığında da, duygusal ülke imajının bilişsel ülke imajına göre ürün-ülke imajına daha düşük bir etki yaptığı söylenebilir. Fakat araştırmaya dâhil edilen ülkelerin tamamında modellenen ilişkinin geçerliliği gözlenmiştir. Dolayısıyla hipotez H4 kabul edilmiştir.

Tablo 7: Araştırmaya Dâhil Edilen Ülkelerin Duygusal Ülke İmajının Satın Alma Niyeti Üzerindeki Etkisini Ölçmek İçin Uygulanan Regresyon Analizinin Özet Tablosu

\begin{tabular}{|c|c|c|c|}
\hline Ülkeler & $\begin{array}{l}\text { Regresyon Analizi } \\
R \text { Değeri }\end{array}$ & $\begin{array}{l}\text { Regresyon Analizi } \\
R^{2} \text { değeri }\end{array}$ & $\begin{array}{lr}\text { Etki } & \text { Eden } \\
\text { Değisskenler } & \text { ve } \\
\text { Katsaylları } & \end{array}$ \\
\hline ABD & ,271 (\%27) & ,073 (\%7) & -Sempatik $(, 162)$ \\
\hline Fransa & ,307 (\%31) & ,094 (\%9) & $\begin{array}{l}\text {-Barışsever }(, 167) \\
\text {-Sempatik }(, 216)\end{array}$ \\
\hline Japonya & ,507 (\%51) & ,257 (\%26) & $\begin{array}{l}\text {-Barışsever }(, 271) \\
\text {-Sempatik }(, 315)\end{array}$ \\
\hline
\end{tabular}

Araştırma çerçevesinde değerlendirilen duygusal ülke imajı ile tüketicilerin satın alma niyeti arasındaki ilişki (Tablo 7 bize önemli bilgiler sunmaktadır. Öncelikle duygusal ülke imajı ile tüketicilerin satın alma niyeti arasındaki ilişkinin varlığının ve şiddetinin ülkeden ülkeye değiştiği söylenmelidir. Bundan başka duygusal ülke imajını oluşturan değişkenlerin her biri tüketicilerin satın alma niyeti üzerinde etkili olmamaktadır. Duygusal ülke imajının "dost" değişkeni hiçbir ülkede anlamlı çıkmamıştır. Bundan başka "barışsever", "işbirliğinde" ve "sempatik" değişkenlerinin bir kısmı belirli bir ülke için geçerli değişkenler olurken, diğer bir kısmı da bir başka ülke için geçerli olabilmektedir. 
Yani duygusal ülke imajı ile tüketicilerin satın alma niyeti arasındaki ilişkinin bu boyutu da ülkeden ülkeye değişmektedir.

Tablo 8: Ürün-Ülke İmajı Aracı Değişkeni İle Duygusal Ülke İmajı Değişkeni İçin Katsayıların Çıktıları Yöntemi Özet Tablosu

\begin{tabular}{llll}
\hline Ülkeler & $\begin{array}{l}\text { Çoklu } \\
\text { Regresyon } \\
\text { Analizi }\end{array}$ & $\begin{array}{l}\text { Basit } \\
\text { Regresyon } \\
\text { Analizi }\end{array}$ & $\mathrm{R}^{2}$ Dolaylı \\
& $R^{2}$ Değeri & $R^{2}$ Değeri & \\
ABD & $0,257(\% 25,7)$ & $0,073(\% 7,3)$ & $0,018(\% 2)$ \\
Fransa & $0,344(\% 34,4)$ & $0,137(\% 13,7)$ & $0,047(\% 5)$ \\
Japonya & $0,589(\% 58,8)$ & $0,256(\% 25,6)$ & $0,15(\% 15)$ \\
\hline
\end{tabular}

Aracı değişken kullanarak uyguladığımız çoklu regresyon analizinde ABD,

Fransa ve Japonya'nın duygusal imajının ilgili ülkelerde üretilmiş ürünlere ilişkin satın alma niyetini doğrudan etkilediği görülmüş̧ür. Bu sonuç hipotez H5'in kabul edilmesini gerektirmektedir. Fakat duygusal ülke imajının satın alma üzerine yaptığ 1 etki ülkeden ülkeye değişmekte olup ABD ve Fransa örneğinde önemsiz düzeyde çıkmıştır.

\section{SONUÇ}

Araştırmanın başlıca bulgularına bakıldığında, araştırmada ele alınan üç ülke olan ABD, Fransa ve Japonya örneğinde, bilişsel ülke imajının ürün-ülke imajı üzerinde etkili olduğu görülmektedir. Fakat söz konusu etkinin düzeyi ülkeden ülkeye değişmektedir. Bilişsel ülke imajının satın alma niyetine olan etkisine bakıldığında da yine ülke bazında farklılıklar göze çarpmaktadır. Bilişsel ülke imajı, ABD ve Fransa' da üretilmiş ürünlere ilişkin satın alma niyetine ürün imajı yoluyla dolaylı olarak etki etmektedir. Fakat bilişsel ülke imajının satın alma niyetine olan etkisi Japonya örneğinde hem dolaylı hem doğrudan hem de önemli düzeydedir. $\mathrm{Bu}$ bulgular bilişsel ülke imajı etki düzeyinin bilinmesinin pazarlamacılar ve devletler açısından stratejik önem taşıdığını göstermektedir. Bilişsel imajın, satın alma niyetine doğrudan etki edebildiği durumlarda kullanılması, satış hedeflerine ulaşmada daha işlevsel olacaktır. Bununla beraber Fransa gibi bilişsel imajın satın alma niyetine dolaylı etki ettiği ülkelerde de işlevsellik söz konusu olabilir. Örneğin araştırmamızda Fransa'nın bilişsel imajının zenginlik bileşeninin ürün-ülke imajı üzerinde etkili olduğu tespit edilmiştir. $\mathrm{Bu}$ bulgu çerçevesinde örneğin Citroen pazarlamacıları Fransız zenginliğini temsil eden ünlü sarayları reklam çekimlerinde kullanarak ürün imajını yükseltebilirler. Böylece dolaylı olarak satın alma niyetine etki edebilirler. Japonya'da üretilmiş ürünlerin reklamında ise, ürünle beraber bazen sadece bir Japon mühendisin kullanılması bile yeterli olabilir. Çünkü Japonya'nın bilişsel imajı satın alma niyetine doğrudan etki etmektedir ve kalifiye iş gücü Japonya'nın bilişsel ülke imajı bileşeninde önemli bir değişken olarak tespit edilmiştir.

Araştırmaya dâhil edilen ülkeler çerçevesinde, pazarlamacılar için bilişsel imajı kullanmanın en faydalı olacağı ülke Japonya olarak belirlenmiştir. Japonya'nın bilişsel ülke imajının satın alma niyeti üzerinde önemli bir etki ortaya çıkarması bu sonucu doğurmuştur. Japonya devleti ve bu ülkede üretim yapan firmalar, bilişsel ülke imajına bağlı gelişmiş ekonomi, yüksek hayat standardı ve 
kalifiye işgücü değişkenlerini kullanarak hem ürün imajlarını hem de ürünlere ilişkin tüketici satın alma niyetini geliştirebilirler. ABD ve Fransa'da üretilmiş ürünleri pazarlayan firmalar ise ürün-ülke imajında etkili olan bilişsel ülke imajı boyutlarını (zenginlik, gelişmiş ekonomi ve kalifiye işgücü) öne çıkararak ürün imajını bir miktar yükseltebilirler ve bu yolla dolaylı olarak satın alma niyetine etki edebilirler. Fakat bu ülkeler için etki sınırlı ve dolaylı olduğundan dikkatli ve detaylı bir fayda-maliyet analizi gerekmektedir.

Araştırmada bilişsel ülke imajından sonra ürün-ülke imajının (ilgili ülkeye ait genel ürün imajının) satın alma davranışı üzerindeki etkisi incelenmiştir. Bu amaçla yapılan regresyon analizinde ürün-ülke imajının satın alma davranışı üzerinde önemli derecede etkili olduğu tespit edilmiştir. Fakat bu etkinin düzeyi de ülkeden ülkeye değişmektedir. Ürün-ülke imajı Japonya örneğinde satın alma niyeti açısından çok önemli bir etki doğuruyorken $(\mathrm{R} 2=\% 58)$, söz konusu etki Fransa $(\mathrm{R} 2=\% 30)$ ve $A B D$ 'de $(\mathrm{R} 2=\% 24)$ nispeten düşüktür. Fakat satın alma niyetine bu seviyede etki yapan bir değişkenin pazarlamacılar tarafından dikkatle ele alınması gerekmektedir. $\mathrm{Bu}$ bulgular çerçevesinde, Türkiye piyasasında Japonya'da üretilmiş ürünleri pazarlayan firmaların üretim ülkesi bilgisini pazarlama faaliyetlerinde kullanmalarının çok önemli bir rekabet avantajı doğuracağ 1 değerlendirilmektedir. ABD ve Fransa için de bu durum aynıdır; fakat Japonya'da üretilmiş aynı kategori ve markaya ait ürünler karşısında dezavantajlı durumda oldukları yorumu yapılabilir.

Araştırma bulguları çerçevesinde bilişsel ülke imajı ve ürün-ülke imajı bakımından $\mathrm{ABD}$ ve Japonya karşılaştırması yapmak önem arz etmektedir. İki ülkenin de bilişsel ülke imajı ve ürün-ülke imajı aritmetik ortalamaları birbirine yakın ve yüksek olduğu halde; bilişsel ülke imajı ve ürün-ülke imajı boyutunun satın alma niyetine olan etkisi iki ülke arasında önemli bir farklılık göstermektedir. ABD'nin Japonya'ya göre hem ülke imajı değerlendirmeleri hem de satın alma niyeti düşüktür. Bu durum marka ve fiyat gibi satın alma niyetini etkileyen ülke imajı dışındaki faktörlerin, ABD'de üretilen ürünler üzerinde Japonya'ya göre daha etkili olduğu sonucunu ortaya koymaktadır.

Araştırmada geliştirilen hipotezlerin diğer bir kısmı da duygusal ülke imajı değerlendirmeleri üzerinedir. Bu çerçevede ele alınan ilk hipotezde duygusal ülke imajının ürün-ülke imajına yaptığı etki incelenmiştir. Yapılan analizler duygusal ülke imajının ürün-ülke imajı üzerinde etkili olduğunu ortaya koymuştur. Fakat bu etki düzeyi de ülkeden ülkeye değişmektedir. Yapılan analizde en yüksek etki düzeyi Japonya örneğinde karşımıza çıkmıştır (R2=\%25). Bu ülkeyi ABD (R2= $\% 5,9)$ ve Fransa $(\mathrm{R} 2=\% 5,7)$ takip etmiştir. Yapılan analizlerde ABD ve Fransa'nın duygusal imajına bağlı değişkenlerin katsayılarının oldukça düşük olduğu ve dolayısıyla ürün-ülke imajlarına çok düşük düzeyde etki edebildikleri görülmüştür. Fakat bu etki düzeyi Japonya için nispeten yüksektir. Dolayısıyla Japon menşeli ürünlerin pazarlamasını yapan kişi ve firmalar için duygusal ülke imajı değişkeninin dikkate değer bir faktör olduğu ortaya çıkmıştır. Pazarlamacılar Japonya'nın duygusal imajına bağlı barışseverlik ve sempatiklik değişkenlerini vurgulayarak ya da bu değişkenlere ilişkin tüketici algısını yükselterek Japonya'da 
üretilmiş ürünlerin imajını olumlu biçimde etkileyebilirler. ABD ve Fransa için bu imkân son derece kısıtlıdır ve ürün imajını geliştirmek açısından duygusal ülke imajına vurgu ve yatırım yapmanın getirisi olmayacağı sonucu çıkarılabilir. Bu iki ülkenin duygusal imajının cevaplayıcılar nezdinde olumsuz olduğu düşünüldüğünde, pazarlama faaliyetleri çerçevesinde duygusal imaja bağl1, örneğin barışseverlik ve işbirliği gibi değişkenlere vurgu yapıldığında tüketicilerin ne derecede ve ne yönde etkilenecekleri, ayrıca verilen mesajları ne kadar ciddiye alacakları birer soru işareti olarak karşımızda durmaktadır. Zira bir ülkeye ilişkin oluşabilecek sevme-sevmeme gibi tüketici tutumları kısa zamanda ortaya çıkmamakta ve kısa zamanda değişmemektedir.

Duygusal ülke imaj1 değerlendirmeleri üzerine test edilen ikinci hipotez, duygusal ülke imajının satın alma niyetine doğrudan etki yaptığını vurgulamaktadır. Bu etki düzeyi de yine ülkeden ülkeye değişmektedir. Duygusal ülke imajının satın alma niyetine yaptığı doğrudan etki Japonya örneğinde en yüksek çıkmıştır $(\mathrm{R} 2=\% 15)$. Bu ülkeyi Fransa $(\mathrm{R} 2=\% 5)$ ve $\mathrm{ABD}(\mathrm{R} 2=\% 2)$ izlemektedir. ABD ve Fransa'nın duygusal imajının ilgili ülkelere ilişkin satın alma niyetine çok düşük düzeyde etki edebildiği görülmüştür. Ancak bu etki düzeyi Japonya için önemli derecede yüksektir. Japon menşeli ürünlerin pazarlamasını yapan kişi ve firmalar için duygusal ülke imajı değişkeninin önemli bir faktör olduğunu bu analiz değerleri de desteklemektedir. Dolayısıyla örneğin Japonya'nın tüketiciler nazarındaki sempatikliği, hem ürün imajını yükseltmek hem de satın alma niyetini arttırmak için pazarlama faaliyetlerinde kullanılabilir. ABD ve Fransa örneğinde ise duygusal ülke imajının satın alma niyetine önemsiz bir etki yaptığı görülmektedir. Bu ülkelerin bilişsel ülke imajının da satın alma niyetine ancak dolaylı bir etki yapabildiği göz önüne alındığında, ABD ve Fransa için ülke imajı değerlendirmeleri açısından satın alma niyetine etki eden gerçek faktörün ürün-ülke imaj1 olduğu görülmektedir. Tüm bu veriler 1şığında Japonya'da üretilmiş ürünler için Türkiye'deki pazarlamacıların bilişsel, duygusal ülke imajı ile ürün-ülke imajını pazarlama faaliyetlerinde kullanmalarının hedef kitle üzerinde önemli düzeyde etki ortaya çıkarabileceği görülmüştür. Bununla birlikte $A B D$ ve Fransa örneğinde ise sadece ürün-ülke imajının (ilgili ülkeye ait genel ürün imajının) satın alma niyetine dikkate değer bir etki yaptığ tespit edilmiştir.

Nihai olarak, ihtimalsiz örnekleme yöntemi kullanılması ve araştırma evreninin yalnızca bir üniversitedeki ön lisans ve lisans öğrencileriyle sınırlı olması nedeniyle, araştırma sonuçlarının Türkiye için genellenmesi mümkün değildir. Bununla beraber, örneklem sayısı yüksektir. Ayrıca araştırma evreni gelir seviyesi, cinsiyet ve ülke içindeki bölgeler itibariyle yeterli çeşitlilik barındırmaktadır. Araştırmada itina gösterilen tüm bu şartlara rağmen ortaya konan değerlendirmelerin, çalışmada incelenen yükseköğretim kurumu öğrencileri çerçevesinde geçerlilik arz ettiği ve ancak farklı çalışmalarla da desteklendiği takdirde Türkiye veya diğer ülkeler için geçerli olabileceği göz ardı edilmemelidir. 


\section{KAYNAKÇA}

Alvarez Maria D., \& Campo, Sara. (2014). The influence of political conflicts on country image and intention to visit: A study of Israel's image. Tourism Management, 40, 70-78. https://doi.org/10.1016/j.tourman.2013.05.009

Apil, Ali Riza., Kaynak, Erdener., \& Nugzar, Todua. (2008). Georgian Consumers' Evaluation of Products Sourced From a Geographically Close Proximity Country. Journal of Euromarketing, Vol. 17(3/4), 199-218. http://dx.doi.org/10.1080/10496480802511331

Askegaard S. \& Ger Guliz (1998). Product-Country Images: Towards a Contextualized Approach. E - European Advances in Consumer Research Volume 3, eds. Basil G. Englis and Anna Olofsson, Provo, UT: Association for Consumer Research, Pages: 50-58. Direct url: ttp://acrwebsite.org/volumes/11153/volumes/e03/E-03

Baron R. M., \& David A. Kenny. (1986). Moderator-Mediator Veriables Distinction in Social Pyscological Research: Conceptual, Strategic and Statistical Considerations. Journal of Personality and Social Psycology, 51(6), 1173-1182. Direct url: http://www.public.asu.edu/ davidpm/classes/psy536/Baron.pdf

Botschen, G., \& Hemettsberger, A. (1998). Diagnosing Means-End Structures to Determine the Degree of Potential Marketing Program Standardization. Journal of Business Research, vol.42, 151-159. https://doi.org/10.1016/S0148-2963(97)00116-1

Bozbay, Zehra. (2007). Tüketicilerin Çok Uluslu Ürün Değerlemelerinde Ürünün Üretildiği Ülke İmajı Ve Marka İmajı Etkilerinin Belirlenmesi. (Yayınlanmamış Doktora Tezi). İstanbul Üniversitesi Sosyal Bilimler Enstitüsü.

Brijs, K., Josée Bloemer ve Hans Kasper, (2011); “Country-Image Discourse Model: Unraveling Meaning, Structure and Function of Country Images, Journal of Business Research, vol.64, pp.1259-1269. doi:10.1016/j.jbusres.2011.01.017

Bumjun, Lee., Hamb, Sunny., \& Donghoon, Kim. (2015). The effects of likability of Korean celebrities, dramas, and music onpreferences for Korean restaurants: A mediating effect of a countryimage of Korea. International Journal of Hospitality Management, 46, 200-212. http://dx.doi.org/10.1016/j.ijhm.2014.05.012

Cengiz, Ekrem., \& Kirkbir, Fazil. (2007). Turkish Consumers' Evaluation of Products Made in Foreign Countries. The Innovative Marketing 3, 2, ProQuest pp. 72.

Chinen, Kenichiro, Carl E. Enomoto., \& Dan L. Costley. (2000). The Country of Origin Effect on Toyota's Made in Japan, USA and Mexico. Brand Management, Vol.8, No.2, 139-148. Doi: 10.1057/palgrave.bm.2540014

Fournier, S. (1998). Consumers And Their Brands: Developing Relationship Theory in Consumer Research. Journal of Consumer Research, vol.24, 343-373. Direct url: http://bear.warrington.ufl.edu/weitz/mar7786/articles/fournier\%20(1998).pdf

Hong, S.-T., \& Wyer, Jr., R. S. (1989). Effects Of Country Of Origin And Product-Attribute Information On Product Evaluation: An Information Processing Perspective. Journal of Consumer Research, 16, 175-187. Direct url: http://morgana.unimore.it/vecchi_patrizia/COO/Hong\%20\&\%20Wyer\%20(1989)_JCR.pd $\mathrm{f}$

Hong, S. T. ve Wyer, R. S. (1990a). Determinants of Product Evaluation: Effects of the Time Interval Between Knowledge of a Product's Country of Origin And Information About Its Specific Attributes. Journal of Consumer Research, 17(3), 277-288. Doi: 10.1086/208557.

İslamoğlu, A. H. ve Ü. Alnıaçık (2016). Sosyal Bilimlerde Araştırma Yöntemleri (SPSS Uygulamalı), 5. Bask1, Beta Yayınevi, İstanbul.

Johansson, J. K. (1989). Determinants And Effects of the Use of 'Made in' Labels. International Marketing Review, vol.6, 47-58. doi: 10.1108/EUM0000000001502

Johansson, J. K. \& Nebenzahl, I. D., (1986); "Multinational Production: Effect on Brand Value", Journal of International Business Studies, vol.17, pp.101-126. doi:10.1057/palgrave.jibs.8490861

Jones, Russel A., \& Richard D. Ashmore. (1973). The Structure of Intergroup Perception: Categories And Dimentions in Views of Ethnic Groups And Adjectives Used in Stereotype Research. 
Journal of Personality and Social Psychology, 25(3), 428-438. http://dx.doi.org/10.1037/h0034162

Judd, C. M., \& Kenny, D. A. (1981). Process Analysis: Estimating Mediation in Treatment Evaluations. Evaluation Review, 5(5), 602-619. doi/abs/10.1177/0193841X8100500502

Knight, G., Spreng, R., \& Yaprak, A. (2003). Cross-National Development and Validation of an International Business Measurement Scale: the COISCALE. International Business Review, 12, 581-599. Doi: 10.1016/S0969-5931(03)00077-5

Laroche, Michel., Papadopoulos, Nicolas., Heslop, Louise., \& Bergeron, Jasmin. (2005). Effects of Subcultural Differences on Country and Product Evaluations. Journal of Consumer Behaviour, Vol.2, No.3, 232-247. Doi: 10.1002/cb.104

Lefkoff-Hagius, R,. \& Mason, C. H. (1993). Characteristic, Beneficial and Image Attributes in Consumer Judgments of Similarity And Preference. Journal of Consumer Research, vol.20, $100-110$.

Li Dongjin, Cheng Lu Wang,Ying Jiang, Bradley R. Barnes \& Hao Zhang. (2014). The asymmetric influence of cognitive and affective country image on rational and experiential purchases. European Journal of Marketing, 48(11/12), 2153-2175. Doi: 10.1108/EJM-09-2012-0505

Li, W.K., \& Monroe, K. B. (1992). The Role Of Country-of-Origin Information on Buyers' Product Evaluation: An in-Depth Interview Approach. Proceedings of the 1992 AMA Summer Educators' Conference, 274-280.

Li, W.K., \& Wyer, Jr., R. S. (1994). The Role of Country of Origin in Product Evaluations: Informational and Standard-of-Comparison Effects. Journal of Consumer Psychology, 3, 187-212. doi:10.1016/S1057-7408(08)80004-6

Kotler, P., Jatusripitak, S., \& Maesincee, S. (2000). Ulusların Pazarlanması. İstanbul: Türkiye İş Bankası Kültür Yayınları.

Maher, A. A., \& Carter, L. L. (2011). The Affective and Cognitive Components of Country Image: Perceptions of American Products in Kuwait. International Marketing Review, Vol. 28, 559-580. doi: 10.1108/02651331111181411

Nebenzahl, I.D., \& Jaffe, E.D. (1996). Measuring the joint effect of brand and country image in consumer evaluation of global products. Journal of Marketing Practice, Vol. 3 No. 3, 190 207. doi:10.1108/EUM0000000004387

Obermiller, C., \& Spangenberg, E. (1989). Exploring The Effects Of Country-Of-Origin Labels: An Information Processing Framework. Advertising and Consumer Research, 16(1), 454-9. Direct url: http://acrwebsite.org/volumes/6946/volumes/v16/NA-16

Parameswaran, R., \& Pisharodi, M. R. (1994). Facets of Country of Origin Image: An Empirical Assessment. Journal of Advertising, 23, (1), 43-56. doi:10.1080/00913367.1994.10673430

Parameswaran, R., \& Yaprak, A. (1987). A Cross-National Comparison of Consumer Research Measures. Journal of International Business Studies, 18, 3549.http://dx.doi.org/10.1057/palgrave.jibs.8490398

Peeter W. J. Verlegh., \& Jan-Benedict E.M. Steenkamp. (1999). A Review And Meta-Analysis Of Country-Of-Origin Research. Journal of Economic Psychology 2, 521-546. doi:10.1016/S0167-4870(99)00023-9

Pewglobal. (2006). Publics of Asian Powers Hold Negative Views of One Another China's Neighbors Worry About Its Growing Military Strength. Retrieved from http://pewglobal.org/reports/display.php?ReportID=255

Roth, Katharina P., \& Adamantios, Diamantopoulos. (2009). Advancing The Country Image Construct. Journal of Business Research, Vol.62, 726-740. doi:10.1016/j.jbusres.2008.05.014

Roth, Katharina P., \& Zabkar, Vesna. (2011). Cognitive, Affective and Symbolic Country Connotations: Conceptual Underpinnings, Interrelationships and Impact on Consumer's Behavioral Intentions. American Marketing Association, Summer, 252-253.

Roth, Katharina Petra Zeugner., \& Žabkar,Vesna. (2015). Bridging the gap between country and destination image: Assessing common facets and their predictive validity. Journal of Business Research, 68, 1844-1853. doi:10.1016/j.jbusres.2015.01.012 
Schoefer, Klaus., \& Diamantopulos, Adamantios. (2008). The Role of Emotions in Translating Perceptions of (In) Justice into Postcomlaint Behavioral Responses. Journal of Service Research, 11(1), 91-103. doi:10.1177/1094670508319091

Sobel, M. E. (1982). Sociological Methodology. S. Leinhardt (Eds.), Asymptotic Confidence Intervals for Indirect Effects in Structural Equation Models (pp. 290-312). Washington DC: American Sociological Association.

Tse, D.K., \& Gorn, G. (1993). An Experiment on The Salience of Country-of-Origin in The Era of Global Brands. Journal of International Marketing, 1(1), 57-76. Direct URL: http://www.jstor.org/stable/25048484

Ulgado, Francis M., \& Lee Moonkyu. (1993). Consumer Evaluations of Bi-national Products in the Global Market. Journal of International Marketing, Vol:1, No:3, 5-22. Direct URL: http://www.jstor.org/stable/25048504

Wang, C. L., Li, D., Barnes, B. R., \& Ahn, J. (2012). Country Image, Product Image and Consumer Purchase Intention: Evidence From an Emerging Economy. International Business Review, 21 (6), 1041-1051. doi:10.1016/j.ibusrev.2011.11.010.

\section{SUMMARY}

Growing competition force marketers to use even the most negligible product attributes as a differentiation tool. In this perspective, country of origin becomes an important differentiation tool as an extrinsic cue. Thus, understanding the effect of country image on product image and purchase intention becomes more important for marketing professionals.

So far, country image studies have important shortcomings in explaining the effect structure of country image. These problems stem from the lack of a clear and coherent definition and inadequate scales. This thesis aims to solve this problem. Within the context of the sample investigated, it approaches more comprehensively to the country image issue and deals with country image differentiations towards three developed countries, namely the USA, Germany, and Japan, which are important to Turkey. To better understand the country image effects, general country image was decomposed of its cognitive country image component and affective country image component with the help of the attitude theory. Then, these two components' effects on product image and purchase intention were analyzed separately. Based on a student survey conducted in Demirci Campus of Celal Bayar University, the findings of this study revealed that cognitive country image is not necessarily consistent with affective country image. In other words, when cognitive country image of a country is positive, at the same time its affective country image may be negative. And through these two components, country image has different effects on product image and purchase intention. The cognitive country image influences purchase intention through product image, and the affective country image has a direct influence, independent of product image. Benefiting from the attitude theory, such a decomposing effect may shed some light on the literature and managerial practices with regards to the effect of country origin on purchase intention. 